\title{
Økonomisk science fiction og kritisk anti-utopi
}

\section{Dave Eggers' The Circle, kognitiv kapitalisme og $ø$ øonomisk subjektivitet}

\section{Indledning: To antagelser om romanen}

I slutningen af Dave Eggers' nær-fremtids anti-utopi The Circle (2013), siger hovedpersonen Mae med lettelse og forsikring i stemmen: "Ten million people were now transparent worldwide, the movement irreversible" (490). Den private tech-virksomhed "Cirklens" bestræbelser på at forme ikke bare sin egen "campus community", men hele verden, ud fra en ide og et ideal om total åbenhed og transparens, er nu en uundgåelig proces. Det opfattes af Mae, som her til slut er blevet det rene ideologiske talerør for virksomheden, som realiseringen af det perfekte samfund, hvor alle kan kende hinanden "truly and wholly", og mennesket ikke mere kan holde sit liv skjult fra andre, eller hvad hun beskriver som "the selfish hoarding of life" (491). For Mae og alle "cirklerne" (dem som direkte arbejder for Cirklen) er det derfor vejen mod virkeliggørelsen af en global utopi, en verden der i sin totalitet er en kvalitativt transformeret verden: "Completion was imminent, and it would bring peace, and it would bring unity, and all that messiness of humanity until now, all those uncertainties that accompanied the world before the Circle, would be only a memory" (491). Som Dave Eggers også selv har påpeget, var hans intention netop at vise techvirksomhedens eutopia: "I wanted Mae to have that feeling that on campus everything is perfected - everything is the best of it's kind [...] Excercise, yoga, doga are all in one place, so the world outside, by comparison, is filthy, chaotic and less desirable" (Jackson). Det er den oplevelse af perfektion og den følelse af renhed på campus, som får Mae til at begære "Completion", og Maes handlinger er altså styret af, hvad utopiforskeren Ruth Levitas præciserer som det utopiske: "the desire for a better way of being and living" (Levitas 1990, 7).

Det er dog samtidig åbenlyst, at denne virkeliggjorte utopi eller eutopien ${ }^{\mathrm{I}}$ i virkeligheden eller, hvad der for mig at se, er det samme, økonomisk er en totalitær anti-utopi, hvor det transparente subjekt er ensbetydende med, at livet selv bliver varegjort, udbyttet og kolonialiseret som entydigt værdiskabende for kapitalen. Gennem denne integrationsproces negeres muligheden for (relativ) autonomi, dvs. 
muligheden for at fastholde aspekter af subjektets levede liv og subjektivitet, som noget der kan eksistere uden for den direkte kapitalistiske værdiskabelsesproces.

Romanens narrativ synliggør altså en modsætning mellem et diskursivt eller subjektivt niveau, dvs. hvordan cirklerne taler, tænker og repræsenterer verden (for andre og sig selv), og så et økonomisk-materielt eller objektivt niveau, som viser, hvordan cirklerne udbyttes på en biopolitisk og totalitær måde. Dette blotlægges gennem Mae og hendes konkrete ansættelse, arbejde og videre opstigning i virksomheden. Om end ideologi og økonomi naturligvis hænger sammen - Maes og andre cirklers identifikation med den utopiske ambition, og følelsen af at være en vigtig brik i skabelsen af en bedre verden, er uundgåeligt forbundet med virksomhedens globale ekspansionsmulighed - så er det min første antagelse, at det især er gennem den økonomiske udbytning og de klassemæssige forhold, som indirekte skitseres herigennem, at vi ser eutopien som anti-utopisk. Disse forhold - økonomisk udbytning og klasse - danner grundlaget for bedømmelsen af eutopien som totalitær. Det økonomiske perspektiv bliver derfor det "kameraøje" - mere end kritiske karakteres perspektiver i romanen - som viser eutopien som anti-utopi, eller som science fiction-teoretikeren Darko Suvin påpeger om anti-utopiens narrative dynamik:

Uf It is a pretended eutopia - a community whose hegemonic principles pretend to its being more perfectly organized than any thinkable alternative, while our representative "camera eye" and value-monger finds out it is significantly less perfect than an alternative, a polemic nightmare. (Suvin, 189)

Vi kan derfor sige, at romanen indbyder læseren til at undersøge den dybere økonomiske virkelighed, som ligger under (erkendt og uerkendt) en bestemt klasses - kognitariatet eller den kognitive arbejder (Berardi 2005; Negri og Vercellone) drømme om en perfekt verden. Romanen lægger sig derfor tæt op ad den realistiske roman i skildringen af Maes vej ind i og den sociale virkeligheds vej mod en bestemt anti-utopisk eutopia. Og netop denne relation mellem realisme, kapitalistisk økonomi og utopisk science fiction er blevet central i forbindelse med en nyere retning i science fiction-forskningen, som er blevet betegnet " $\varnothing$ konomisk science fiction" (Davies 2018a). Her er et af fokusområderne, hvordan science fiction-genren (fremover SF) kan udfordre kapitalismen fra et økonomisk og utopisk perspektiv.

Min anden antagelse er derfor, at vi konkret skal læse The Circle og den økonomiske virkelighed, som ligger under den utopiske virkelighed, som følgende: Romanen tager fat i specifikke tendenser i vores egen $\varnothing$ konomiske samtid, centreret om udbytningen af den kognitive arbejders subjektivitet, og lader sig derfor "læse sammen" med teorien om kognitiv kapitalisme (Boutang, fremover KK). Disse tendenser forlænger romanen ud i en mulig fremtid ved at skabe et fiktionelt forestillingsrum, hvori romanen detaljeret kan undersøge, hvordan virkeligheden kunne tage sig ud. Romanen er som anti-utopisk science fiction netop interesseret i denne fremtidige, mulige økonomiske virkelighed, og det interessante for mig er således, hvordan romanen og den økonomiske teori taler sammen, dvs. hvordan de har det samme interesseobjekt (kognitive arbejder og økonomisk udbytning), men giver os 
det på forskellige måder: Hvor den økonomiske teori giver os viden om kapitalismen, giver romanen os et fremtidssyn, en måde at "se" og "føle" en mulig udvikling, og dermed alluderer den til den selvsamme kapitalistiske virkelighed i mere spekulativ form. Men som vi også skal se, er selv denne grænsedragning heller ikke helt klar, da også Yann Boutang i Cognitive Capitalism bruger retoriske midler fra science fiction-genren.

Artiklen vil falde i tre dele: først vil jeg uddybe spørgsmålet om utopi, anti-utopi og realisme i kontekst af "økonomisk science fiction". Denne del vil understrege, hvorfor vi skal læse romanen som en bestemt historisk form for nær-fremtids antiutopi. Det vil lede over i anden del og en konkretisering af, hvordan vi kan forstå den $\varnothing$ konomiske virkelighed, som romanen forlænger, gennem teorien om KK. I sidste del vil jeg analysere romanen med henblik på det økonomiske perspektiv, der synliggør Cirklens anti-utopiske eutopi, gennem dennes biopolitiske akkumulationsmåde og de forskellige måder, som Mae som økonomisk subjekt kontrolleres og udbyttes på.

\section{Utopisk og anti-utopisk science fiction: utopiens klasseforhold}

$\varnothing$ konomisk science fiction er en retning inden for SF-studier, eksemplificeret ved antologien Economic Science Fictions (Davies 2018a), som eksplicit søger at fremhæve og bruge SF-genren som et modsvar til neoliberalismens hegemoni (Davies 2018b, 18), eller hvad Mark Fisher har kaldt "capitalist realism": Hvordan kapitalismen siden 1970'erne har neutraliseret vores forestillingsevne, ved at tage patent på, ikke kun hvad der er, men lige så vigtigt, hvad der kan være økonomisk muligt. Interessen for SF-genrens økonomiske fiktioner er altså et modsvar til Fishers diktum om, at det nu er "impossible even to imagine a coherent alternative to it [capitalism]" (Fisher 2009, 2).

Hvor denne stemning af en lukket, alternativ fremtid især har produceret dystopien som dominerende kulturel forestilling (Levitas og Sargisson 2003, 14; Fisher 2009, 2-3), så retter Fisher opmærksomhed mod den økonomiske SF som en art ideologisk modoffensiv. I forordet til antologien Economic Science Fictions (Davies 2018a), som også er dedikeret til ham (han begik selvmord i 2017), understreger han behovet for en type økonomisk SF, som kan give os måder at forestille og tænke alternativer til kapitalistisk realisme:

4 Capital's economic science fictions cannot simply be opposed; they need to be countered by economic science fictions that can exert pressure on capital's current monopolization of possible realities. The development of economic science fictions would constitute a form of indirect action without which hegemonic struggle cannot hope to be successful [...] Fictions, that is to say, can counter capitalist realism by rendering alternatives to capitalism thinkable. (Fisher 2018, xiii-xiv)

$\emptyset$ konomisk SF er her for Fisher, som for William Davies (2018b) og Laura Horn (2018), lig med "real Utopias" eller eutopier, dvs. virkeliggjorte og bedre alternativer til det kapitalistiske økonomiske system (ejerskab og private virksomheder) 
og dets sociale forhold (klassesamfund). Gennem denne distancering fra nutiden anfægtes de "fiktioner", som den eksisterende økonomiske virkelighed tager som urokkeligt virkelige, og som den lader herske over den sociale virkelighed, fx virksomheder som en "social fiction" (Horn 2018, 43; Davies 2018b) eller hvordan subjektet er formet af og spundet ind i ukontrollable og transpersonale fiktionelle systemer som finansinstrumenter, risikomodeller og automatiseret teknologi (Davies 2018b, 23; Fisher 2018, xiii). Det centrale er dog, at fokusset i økonomisk science fiction ikke kun er på kritik og det oppositionelle, men derimod også har et fokus på og en læsning efter virkeliggørelsen af andre positive måder at leve og være på, dvs. hvordan subjektivitet, sociale forhold og økonomiske institutioner aktivt betinger hinanden (Chang 2018, Horn 2018, Fisher 2018).

Hvad denne side af økonomisk science fiction - forstået som både en økonomisk tilgang til SF og som en afgrænsning af et empirisk genstandsfelt (SF-værker, der viser disse økonomiske alternativer) - efterspørger, er altså science fiction-genrens utopiske side. Med andre ord, hvis vi tænker med Levitas, så taler denne retning hos Fisher, Davies og Horn om utopien som en mellemting mellem transformativ og kritisk (Levitas 1990, 168-174, 192-197). Som Levitas påpeger, er der et funktionelt skel mellem disse to: hvor de begge er rettet mod en beskrivelse og lokalisering af et samfund i fremtiden - altså den alternative, økonomiske virkelighed, for at blive i økonomisk SF regi - er den kritiske utopis funktion at bruge denne lokalitet som et redskab til kritik af det eksisterende system (som et spejl der holdes op), men uden at have et fokus på, hvem der kan frembringe selve den sociale transformation, som har ført til denne realisering af utopien i fremtiden. Med den transformative utopi mener Levitas specifikt den utopi, som er optaget af "thinking through the process of transformation from the present, and identifying the potential agents of that transformation" (Levitas og Sargisson 2003, 14). Den transformative utopi er altså optaget af handling og agens, af hvordan begæret efter "a better way of being and living" (Levitas 1990, 7) i praksis kan realiseres.

Her er vi inde ved kernen af revolutionær, systemforandrende tænkning: Hvem kan lokaliseres som revolutionære subjekt(er), som kan iværksætte denne sociale transformation? For Fisher, Davies og Horn er svaret herpå uklart, og i den forstand er deres utopiforståelse, om end de trækker på Levitas, mere relateret til den kritiske utopi (hvilket også flugter med Fishers' tøvende bemærkninger om "agency" i Capitalist Realism). Men netop fordi forholdet mellem utopi og handlingsagent(er) er relativt ustabilt i denne retning, så åbnes der også op for en konflikt mellem divergerende utopier (se også Levitas 1990 for en sådan analysemåde), som når William Davies skriver: "Unless possibilities for broader economic transformation are rediscovered, then the future will belong entirely to those Silicon Valley entrepreneurs and the utopias they bring with them" (Davies 2018b, 27). Davies åbner selv her indirekte op for et "anti-utopisk" perspektiv, fordi vi har med klasseforhold at gøre: en utopi for de få, som i realiteten er en dystopi for majoriteten (27-28). Eller som SF-teoretikeren Darko Suvin siger om kapitalismens evne til at neutralisere det utopiske (igen med et særligt fokus på tiden efter 1970’erne), ved selv at gøre krav på ordet: 
4 capitalism co-opts all it can from utopia (not the name it abhors) and invents its own, new dynamic locus. It pretends this is a finally realized eutopia (end of qualitative history); but since it is in fact for the 85 percent of humanity clearly and 13-14 percent subterraneously a dystopia, it demands to be called Anti-Utopia. (Suvin, 192)

Så er vi tilbage ved Mark Fisher og "capitalist realism", men nu med et nyt, udvidet problem: Hvis utopien og den utopiske tænkning er, hvad der kaldes på fra én side af den økonomiske science fiction-retning, hvad gør man så med den utopi, som viser sig at være klassebaseret fra "det forkerte perspektiv" (kapitalejere)? Hvad, for eksempel, med den Silicon Valley entreprenør-klasse, som Davies taler om, som ønsker at konstruere en virkelig utopi for de meget få, baseret på og opretholdt gennem udbytningen af alle andre - også det priviligerede kognitariat, som Mae i romanen bliver en del af (for et skel mellem et privilegeret og prekært "cognitariat", se Negri og Vercellone, 110), og som Suvin også påpegede (13-14 procent af befolkningen). Det er stadig på den ene side en utopi i form af "the desire for a better way of being and living" (Levitas 1990, 7), men fra et andet perspektiv er det også en kritik af en utopi som ekskluderende og totalitær. I kraft af fraværet af en universel utopi (Levitas 1990, 184) falder vi (som læsere, som mennesker) tilbage på en moralsk bedømmelse af utopien, en bedømmelse som romanen også selv giver.

Hvis anti-utopien, som adskilt fra dystopien, kan defineres som det værk, der eksplicit er rettet mod en kritik af utopien og utopisk tænkning (Baccolini og Moylan, 5), må det allerede her kvalificeres sådan, at Eggers roman er en historisk-specifik kritik af den utopiske tænkning som udgår fra Silicon Valley - også i 1990'erne døbt "the Californian Ideology" (Dyer-Withford 2015, 64), og hvis posthumane fremtidsforestillinger er en eksplicit italesat vision, dvs. sammensmeltningen af maskine og menneske (O'Connell, 6-7). Denne utopiske tænkning baserer sig på en kombination af teknologibegejstring, kreativ innovationsdyrkelse og den private virksomhedsinstitution, som grundlag for en kvalitativt bedre social transformation. I en dialog til slut i The Circle advarer den ene af grundlæggerne Mae om, hvad der er ved at ske, og hvorfor Cirklens verdensomspændende utopi ikke må realiseres: "Stenton [en anden af ejerne og skaberne af virksomheden] professionalized our idealism, monetized our utopia [...] Everyone becomes a citizen of the Circle" (484). Men Mae er nu så integreret i Cirklens utopiske vision, at hun ikke mere kan genkende denne advarsel og se denne fare. For hende er utopien blevet sand, som vi så i starten af artiklen.

Men denne kvalificering af utopi-kritikken er vigtig, da den modgår dele af en potentiel kritik, som kunne rettes mod romanen, nemlig at dens anti-utopianisme er en legitimering af status quo. For som Levitas påpeger om anti-utopien, og som flugter med Suvins pointe tidligere: "The term utopia itself has been tarnished by association with totalitarianism. This is partly the result of deliberate attempts to invalidate any proposed alternative to capitalism; anti-Utopianism is a standard weapon in the armory of the status quo" (Levitas 2003, 15). Kvalificeringen er altså, at Eggers roman skal læses som en kritik af en specifik form for utopisk tænkning og ikke som en kritik rettet mod den utopiske tænkning som sådan. Der er dog ingen tvivl om, at en eventuel positivt bedømt utopi er skubbet uden for romanen, så at 
sige, og ikke mere repræsenteres inden for romanen som et reelt alternativ. Sagt med andre ord er der ingen positivt bedømt transformativ handlingsagent $\mathrm{i}$ teksten. Men modsat den uklarhed, som Fisher, Davies og Horn har i relation til spørgsmålet om "agency", så er Eggers klar: Det er kognitariatet, ledt af kapitalejende techguruer, som skaber den sociale transformation. Det er, for at omformulere Franco Berardi lidt, "the dark side of the cognitariat" (2005; 2011), en slags pervertering af "agency", som følger en version af den klassiske trope om det idealistiske subjekt, der bringer en destruktiv realitet med sig.

Men i fraværet af positivt bedømte handlingsagenter står vi primært tilbage med anti-utopiens advarsel (Levitas 1990, 165). Hvor Mae overhører alle advarsler (fra Mercer, hendes forældre, Ty etc.), må læseren lytte. Som Eggers også selv påpeger, er intentionen med hans roman at fremsætte en advarsel mod de farlige tendenser i det 21. århundrede såsom overvågning, monopolvirksomheders magt og teknologiens undertvingelse af mennesket (Jackson, se også Galow 2014, 125). Her er antiutopiens funktion at vise frygten ved en bestemt utopis sociale transformation, dvs. hvad der kan ske i fremtiden, hvis vi ikke handler i tide. Videre kan man også sige, med romanens spekulative forlængelse af bestemte tendenser i nutiden in mente og gennem en omskrivning af Williams $(1956,17)$, at romanen ikke kun er en advarsel om fremtiden, men også en advarsel om nutiden, og det, som potentielt er på vej til at blive en fremtid, bliver normaliseret og naturliggjort. The Circle bliver derfor en konkret advarsel mod en herskende utopisk tænkning i Silicon Valley og mere kompliceret: Frygten for, at den kognitive klasse lader sine drømme om en bedre verden blive "købt" (materielt og ideologisk) af denne utopiske form. Jeg vil således sige, at Eggers roman i kraft af sin specifikke utopi-kritik kan læses som en kritisk anti-utopi: kritisk, fordi den stiller skarpt på, hvad både Suvin, Levitas og Davies påpeger, er et træk ved kapitalismen, nemlig dens appropriation af den utopiske tænkning som redskab til at fremme kapitalistiske ejerskabsforhold og økonomisk udbytning, hvilket vi skal se tydeliggjort i de to følgende afsnit.

Men inden vi går videre og ser mere konkret på Cognitive Capitalism og The Circle, bringer ideen om advarsel os til spørgsmålet om realisme. Jeg har beskrevet Eggers' anti-utopiske SF-roman som nær-fremtids roman, og dette er væsentligt, fordi det skal understrege romanens føromtalte relation til den realistiske roman og dermed til den samtidige kapitalismes specifikke akkumulationsmåde centreret om den kognitive arbejder. Den marxistiske kulturteoretiker Raymond Williams peger netop på denne forbindelse mellem den anti-utopiske SF-genre og det realistiske: Betegnelsen "Putropia", som Williams sætter i kontrast til den "realisme-overskridende" genre Space Anthropology, dækker over en pervertering af den utopiske romance. Den er fortællinger om et fremtidigt "secular hell", som er båret af, hvad han kalder "external realism": Genren opererer ud fra "an extension of obvious contemporary tendencies" (Williams 1956, 15-16). Om end Williams selv fokuserer på den dystopiske genre og de klassiske dystopiske værker som Brave New World og 1984, så er det lige så oplagt at medtænke Williams' pointe om realisme i forhold til den specifikt anti-utopiske genre i kraft af hans specifikke understregning af "perverteringen" af det utopiske.

For det afgørende er, at vi ser, hvordan Williams tager fat i realismens markører, hvilket her betyder genrens eksplicitte brug af og henvisninger til en genkendelig, 
ydre virkelighed, og påpeger, hvordan denne genre opererer med en forlængelse af disse genkendelige, eksisterende tendenser i nutiden/samtiden. Denne SF-genre er altså relateret til den realistiske roman og forsøger at trække noget ud af samtiden, forlænge og forstørre det til en hel virkelighed, hvad Williams også andetsteds kalder genrens "formel" (Williams 1961, 45), dvs. den foretager en slags abstraktion fra virkelighedens pluralitet. Denne realistiske del af romanen får vi netop bekræftet, når vi ser, hvordan CC og romanen "taler sammen" gennem den økonomiske udbytning af subjektet. Den eutopi, som Cirklen har indstiftet i det "campus community", som afgrænser virksomheden for omverdenen, er båret af et økonomisk akkumulationssystem og en regulering af arbejde, som kan begribes sammen med teorien om kognitiv kapitalisme: Vi træder nu mere ind i det specifikt økonomiske, og ærindet er i anden del af artiklen at sætte fokus på, hvordan den økonomiske virkelighed er grundlaget for det anti-utopiske perspektiv, eller som Suvin formulerede det: kameraøjet, som viser os utopiens klasseforhold.

\section{Kognitiv kapitalisme og bioproduktion: udbytning af livet selv}

I beskrivelsen af den nutidige kapitalisme som KK, eller hvad der også kaldes den "tredje fase" i kapitalismens historie (Boutang, 9, 50 og Negri og Vercellone, 102104), påpeges tre centrale ændringer: i den private virksomhed som økonomisk institution, ændringer i teknologi i form af digitalisering, netværk og informationsdeling, og forandringer i produktionen af subjektivitet i form af ændring i arbejde og udbytning (hvordan arbejderen skaber værdi for virksomheden).

Jeg vil tage mit udgangspunkt i Yann Moulier Boutangs bog Cognitive Capitalism (2011), men samtidig supplere og trække på Antonio Negri og Carlo Vercellone, som er anerkendt som ledende teoretikere af KK (Dyer-Witheford og de Peuter 2009 og Michael A. Peters og Ergin Bulut). Årsagen til, at jeg vil tage mit udgangspunkt i Boutang, er, at der i konteksten af SF-genren og den nære fremtid er noget interessant $i$, at Boutang selv tænker KK som en "emerging reality" (47). KK skal derfor ikke begribes som fuldt ud virkeliggjort, men derimod som en tendens. Boutang vil undersøge denne tendens i tiden, ikke blot gennem en empirisk tilgang (dataindsamling), men teoretisk gennem udvikling af en hypotese om denne tendens. Denne hypotese skal fungere som en ramme til at forstå den empiriske virkelighed og den transformation, der finder sted (60). Han læner sig derfor, kunne man sige, op af den nære fremtids SF-genres "toolkit", for at låne en formulering fra SF-forfatteren William Gibson (46). Den teoretiske hypotese rummer nemlig et element af forestilling, som nødvendig for at tegne konturerne af tendensen i nutiden. Boutang understreger dette moment af forestilling i kraft af, at hypotesen, for at være effektfuld, for at indfange denne tendens, må overdrive: "we need to privilege this tendency, even to the point of exaggeration, in order to bring development out of the shadows" (60, min kursivering).

Denne overdrivelse ser vi blandt andet manifestere sig retorisk i teksten, når han til tider stopper op og påpeger, at det, han her analyserer, er "[...] the forms representing the future of capitalism [...]" $(131,136)$. Uden selvfølgelig at anfægte værkets videnskabelighed kunne man tale om en form for plotmæssig strukturlighed 
mellem Boutang og Eggers: Begge er optaget af at spore, hvilke tendenser og former i nutiden, der indeholder fremtiden i sig. Hvor Boutang i den politiske økonomis genre synliggør denne tendens gennem overdrivelse for derved at producere en viden og fortælling om nutiden og fremtiden, dvs. "plotte" (selektion, blanding af tider, type narrativ (faser) etc.), dér søger Eggers i SF-genren selvsamme tendens, men forlænger den ud i fremtiden som konkretiseret virkelighed. Med andre ord: Eggers tager Boutangs overdrivelse - $\mathrm{fx}$ det kognitive arbejdes hegemoni i værdiskabelsen (profit) og den kognitive arbejders udbytning (subjektivitet) - længere ud, fordi han søger at vise, hvilken virkelighed denne tendens ført ud i sin faktiske og følbare realitet skaber. En tendens, hvor kapitalismen på afgørende steder forlader sig mere og mere på kreativ "brain-power" (i produktion, profitskabelse, arbejdere, arbejdsformer etc.) end på mekanisk-fysisk "labor-power".

Overordnet påpeger Boutang, at KK indstifter, hvad han kalder for et nyt "akkumulationssystem" (56-57). Det består af to sider: en akkumulationsmåde og en produktionsmåde. Dette kan forsimplet sagt siges at betegne et skel mellem på den ene side, hvad der produceres, dvs. de immaterielle produkter, som virksomheden producerer (software, sociale medieplatforme, intellektuelle ejendomsrettigheder, som fungerer som en ny form for "rent", se Vercellone 2010) og tjener penge på. På den anden side, hvordan denne værdi skabes, dvs. den organisering af arbejdskraft, type af arbejdskraft (uddannet, kognitive arbejdere) og brug af teknologi, som skaber grundlaget for akkumuleringen af immaterielle objekter/kapital.

Med denne skelnen påpeger Boutang, at KK er et radikalt andet akkumulationssystem end den industrielle kapitalisme, som var centreret omkring fabrikken, fysiske produkter og maskineri samt organisering af manuelt arbejde. Med fremkomsten af KK ser vi et akkumulationssystem, hvor dets akkumulationsmåde er baseret på viden, innovation og produktion af immaterielle objekter. Virksomhedens primære indtjeningsmåde er derfor konstant at indfange ny viden og innovation: "the capture of gains arising from knowledge and innovation [...] in which the object of accumulation consists mainly of knowledge, which becomes the basic source of value" (57, 5051, se også Vercellone, 105). Dette skaber omvendt nye betingelser for organisering af arbejde og hvilken type arbejde, som er central. Med andre ord følger der også en ændring i produktionsmåde, hvor det nu er "the cooperative labour of human brains joined together in networks by means of computers", som er det primære vilkår, som bestemmer, hvordan arbejde må organiseres og indfanges i virksomheden.

Dette kan af gode grunde lyde lidt abstrakt, men pointen er følgende: Under KK ser vi, hvordan værdi skabes gennem interaktionen mellem "intellekter", et "kognitariat", som producerer ny viden (innovation) gennem brugen af viden (55). Det er et skift i værdiskabelse fra "labour-power" til "invention-power". Denne interaktion er foranlediget af digital teknologi, og hvad Boutang kalder det digitale netværks "strukturelle merværdi" (65): Den enkelte modtager i et netværk fordele, som han/ hun ikke betaler for. Digital netværksteknologi (Intranet og Internet) er både en betingelse og mulighed for at indfange den form for værdi, som skabes gennem samarbejdet mellem intelligente, innovative hjerner.

Det afgørende for virksomheder under KK er denne indfangelse ("capture") af viden, som "kognitive arbejdere" skaber gennem deres intellektuelle kapacitet for 
opfindsomhed, samarbejde og kreativitet. Eller hvad Boutang kalder skabelsen af "positive eksternaliteter" $(22,55)$, som i den ortodokse, økonomiske teori kan siges at være det, der falder uden for den traditionelle økonomiske aktivitet (arbejdstid og løn).

Dette punkt er helt centralt, og en måde at forstå dette på er at tænke det i forhold til tid (se også Brand). Under den industrielle kapitalisme blev den manuelle fabriksarbejder udbyttet som abstrakt arbejde. Skabelsen af merværdi og dermed profit for kapitalisten lå i, at arbejderen abstrakt set (altså kun fra bytteværdiperspektivet og ikke fra produktionen af brugsværdi) arbejdede mere (det gælder både arbejdsdagens længde samt intensiteten i arbejdet, dvs. produktivitet), end han fik $1 ø n$ for. Men under KK er det værdiskabende ikke mere afgrænset tidsligt og stedligt på den måde, dvs. at indfange de førnævnte "positive eksternaliteter" - alt det som gøres og skabes "uden for" arbejde - betyder, at det egentlig er livet selv, som søges indfanget. KK er derfor ifølge Boutang kendetegnet ved dets "bio-production" (55) og "biopower" (149-151), eller hvad den engelske professor i virksomhedsteori Peter Fleming kalder "biocracy" (2014). Det vil med andre ord sige, at fordi viden produceres af "levende arbejdskraft", dvs. viden skabes ud af et konstant overskud af "invention-power", som ikke kan reduceres til standardiserede eller mekaniske processer (Boutang, 32), så er det også "livet selv", hele arbejderens liv og "det hele menneske", som må indfanges, reguleres og udbyttes. Det betyder konkret, at arbejdet aldrig stopper, at hele ens liv bliver til arbejde, hvor grænsen mellem arbejde og det at leve, livet uden for arbejde, nedbrydes (Fleming, 41). Boutang påpeger derfor, at vi ser en ny form for "udbytning" af den kognitive arbejder, hvad han kalder "exploitation at degree 2" (97): Det er den kognitive arbejders invention-power som udbyttes, men dette, som vi har set, indbefatter nu hele livet.

Det handler nu om for virksomhederne at sørge for, at den kognitive arbejder ikke føler sig fremmedgjort eller tingsliggjort, da dette vil hindre den kreativitet og innovation, som er grundlaget for KK's akkumulationssystem (94). Bioproduktion betyder et fokus på produktion af subjektivitet, dvs. det peger mod en regulering af subjektet i form af en aktiv transformation af det levede liv eller det hele menneske til homo economicus (fremover forkortet HE). Det betyder med andre ord, at alle subjektets aktiviteter (tanker, følelser, handlinger, søvn etc.), det hele, levede liv, bliver indfanget og gjort værdiskabende for virksomheden.

For at skabe denne transformation benytter KK nye motivationsformer. Det er ikke nok at gøre subjektet økonomisk afhængig af kapital, dvs. den "traditionelle" ide om HE som nytte-maksimerende individ, hvis rationelle adfærd er bestemt af $\varnothing$ konomisk kalkulation. Om end dette selvfølgelig i et kapitalistisk samfund stadig spiller en helt afgørende rolle (fx gennem finansialisering og gæld, se Vercellone, 107), er det ifølge Boutang lige så vigtigt at påpege en ny, supplerende tendens. Den måde som KK udbytter den kognitive arbejder ved at manipulere det begær, som han kalder "libido sciendi" (Boutang, 76): begæret efter viden og kognitiv rekreation, den følelse af glæde og begejstring, som mennesker får, når de skaber og finder på nye løsninger. Jeg kan ikke lade være med at supplere Boutang fra den forrige analyse af det utopiske ved at gentage, hvordan vi også kan se KK udnytte det utopiske begær efter en bedre måde at leve og være på (Levitas 1990). Både 
manipuleringen af begæret efter viden og det gode liv er således centrale repressive mekanismer, som indfanger subjektet som økonomisk subjekt.

Hvordan KK producerer og regulerer denne "nye" form for økonomisk subjektivitet gennem biomagt, reguleringer og indfangninger af det levede liv peger mod en virkelighed, som ifølge Boutang kommer til at ligne "characters in a SciFi cartoon" (Boutang, 151). Det er her, at Eggers roman træder ind: Hvis virkeligheden næsten er på vej til at ligne SF, så er det oplagt at se mod SF-genren for at få kastet lys over virkeligeden.

\section{Dave Eggers' The Circle: det transparente subjekt og klasseforhold}

Man kan starte med at spørge: Hvad motiverer hovedpersonen Mae til at arbejde for virksomheden Cirklen i første omgang? Romanen leverer et interessant generationelt svar: som så mange andre i hendes generation har det at blive en relativt højtuddannet kognitiv arbejdskraft betydet en ophobning af gæld, som medfører, at hun mod sin vilje må arbejde for en forsyningsvirksomhed (gas og elektricitet) i sin hjemby. Romanen begynder derfor med at blotlægge, hvordan Mae må gå på kompromis med sine drømme om fremtiden, hendes "rare and golden dreams" (10). Som hun selv med forurettelse i stemmen siger: "She had not gone to college, $\$ 234,000$ worth of elite liberal arts education, for a job like that. But it was work and she needed the money" (9).

Maes forventning om et stimulerende (arbejds-)liv i kraft af den store investering i uddannelsesniveau betyder, at hun føler, at hun spilder sin tid og sit liv. Virksomheden føles som en fortidig verden, der hindrer, at både hun selv, men også hele menneskeheden, kan udfolde sit potentiale, som hun påpeger: "that [it] was not just wasting her life but that this entire company was wasting life, wasting human potential and holding the turning of the globe" (11). Mae føler med andre ord ikke, at hun kan blive den, som hun har potentiale til at blive, ved at være i denne type virksomhed, tværtimod: "that job bent her into something else, into someone who would do anything to leave" (11). Men mere end det. Vi ser her romanens eksplicitte italesættelse af det "utopiske begær", dvs. drømmen om at skabe en kvalitativt bedre verden at leve $\mathrm{i}$.

Gennem Mae, forstået som en repræsentant for en bestemt generation og klasse i samfundet, ser vi romanen lægge ud med en klassisk grundkonflikt i næsten roman-realistisk forstand: Mellem Maes subjektive idealer (fremtidsforestillinger, et meningsfuldt liv, menneskeligt potentiale etc.) og en objektiv, social ydre verden, som hun er fremmedgjort over for. Men i romanens specifikke kontekst er det idealer, der, som nævnt, synes at være kommet fra erfaringen af og investeringen i uddannelse. Konflikten har altså et specifikt socialt og kognitivt aspekt og peger på den simple kendsgerning, at med uddannelse kommer andre forestillinger om fremtider, som, krydret med en "humanistisk" forståelse af det enkelte individs egen værdi og potentiale, făr hende til ikke blot at længes væk, men til at ønske, at hun aktivt kan bidrage til at gøre verden til et bedre sted.

Med adgangen til en moderne tech-virksomhed som Cirklen ændrer denne konflikt terræn. Hvor Mae før blev en person, der ønskede at flygte (fra forsyningsvirk- 
somheden), bliver hun til en person, som ønsker at (for-)blive inden for Cirklens ideal-verden. Det er den førnævnte grundkonflikt, bare vendt om: Nu mellem Cirklens perfekte campus-virkelighed og den rodede, uperfekte verden uden for.

Dette peger altså på en afgørende homologi mellem subjekt og objekt, mellem medarbejder og virksomhed, mellem Mae og Cirklen: dens ideologiske betragtning af mennesket som "a full, knowable human being of unlimited potential" (180) taler lige ind i Maes selvforståelse og drømme. Maes motivation for at arbejde for Cirklen er i første omgang grundet i denne følelse af identitet: at finde sig til rette og opleve en harmoni mellem sig selv og omverdenen. Denne harmoni er nøje tilrettelagt og orkestreret af virksomheden, som fokuserer på en produktion af mental og fysisk "overflod", dvs. på eksplicit at løse det "scarcity gap" (Levitas 1990, 161-164), som Maes klasse oplever, dvs. de socialt-konstrueret behov, ønsker og længsler, som er knyttet til hende som subjekt i en bestemt position i samfundet. Jeg nævnte indledningsvis Eggers' ambition om at fremskrive følelsen af perfektion i livet inden for Cirklens område, og nu kan denne harmoni og perfektion yderligere kobles til ideen om selvoptimering og -udfoldelse gennem interaktionen med og nærheden til de andre kognitive arbejdere eller cirkler: Mae træder ind i en verden af udvalgte mennesker, hvor "the brainpower was phenomenal. It was a place, where everyone endeavored, constantly and passionately, to improve themselves, each other, share their knowledge, disseminate it to the world (105). Vi er altså på en måde her i hjertet af Boutangs KK, hvor det er "brainpower", som interagerer, deler viden, og hvor nye ideer skabes konstant og føres lige så hurtigt ud i livet. Motivationen er at skabe en bedre verden, en flot og hel verden.

Kigger vi nu mere specifikt på romanens forestillinger om kapitalismens akkumulationssystem og spørgsmålet om bioproduktion, dvs. hvad og hvordan Cirklen producerer værdi, tjener penge og udbytter den kognitive arbejder, så springer forholdet mellem idealer og økonomi i øjnene. Romanen opererer med tre spor på karakterniveau, som det fremkommer i samtalerne mellem Mae og de andre kognitive arbejdere. For det første og som det mest dominerende spor ignoreres den økonomiske del, og der er kun en italesættelse på det ideologisk-diskursive niveau, som vi har set, af de idealer som styrer verden mod et bedre sted, dvs. den utopiske diskurs. For det andet anerkendes denne potentielle konflikt mellem idealer og økonomi undertiden, men den opløses, da idealitet og humanitet italesættes som vindere over $\emptyset$ konomisk realitet og virksomhedens profitmaksimering. For det tredje synliggøres den bagvedliggende økonomiske model og virkelighed gennem små glimt i romanen, som eksempelvis når Mae får at vide, at:

Uf the Circle would not exist, and would not grow, and would not be able to get closer to completing the Circle, if there were not actual purchases being made, actual commerce spurred. We're here to be a gateway to all the world's information, but we are supported by advertisers who hope to reach customers through us, right? (248)

Disse huller af økonomisk realitet træder frem, fordi Mae bliver ansat i kundeserviceafdelingen, hvor hun skal stå for håndtering af de virksomheder, som betaler Cirklen for reklamer, og her lyder det også i starten: "it's the foundation of every- 
thing that happens here" (47). Her går det op for Mae, hvor meget andre virksomheder er afhængige af Cirklen "to get the word out about their products, to track their digital impact, to know who was buying their wares and when" (55).

På baggrund af sådanne steder kan man altså sammenstykke, at den måde, som Cirklen tjener penge på, og den måde, som de kognitive arbejdere skaber værdi på, som minimum er en trefoldig værdiskabelsesproces: a) produktionen og vedligeholdelsen af immaterielle produkter som deres sociale medieplatforme, søgemaskine samt adgang til information om brugere, som er grundlaget for reklameindtægter; b) at den enkelte medarbejder selv gennem brugen af selvsamme immaterielle produkter bliver genstand for reklamer og dermed bidrager til virksomhedens indtjening herigennem; og c) at den enkelte medarbejder også selv skal stimulere til køb af produkter gennem anbefalinger udmålt i virksomhedens "Conversion Rate" (248), der måler, hvor effektivt ens anbefalinger bliver lyttet til og afføder køb hos ens følgere, som den enkelte også anspores til at kultivere og måle.

Dette skulle gerne gøre det klart, at den kognitive medarbejders værdiskabelse stiger, jo mere, han/hun er i gang med de ovennævnte aktiviteter. Det betyder også, at Mae med det samme bliver konfronteret med konflikten mellem arbejde og ikkearbejde/fritid, nu italesat af Cirklen som en konflikt mellem at være en del af og ikke være en del af fællesskabet. Den "work-life balance, you know, the calibration between your online life here at the company and outside it" (99-100), som Cirklen understreger, da Mae lige er begyndt, viser sig i virkeligheden at være lig med, at man lever "inden for" virksomhedens bestemmelser. Det vil med andre ord sige, at man konstant deltager i en strøm af online, kommunikativ feedback, deling, anbefalinger etc.

Men denne kolonialisering af den kognitive medarbejders liv og tid er igennem romanen ikke uden mulige brud og afmonteringer. For at Mae selv bliver et fuldt transparent subjekt, hvis konstante online-tilstedeværelse og aktivitet betyder en konstant indtjeningsstrøm, benytter Cirklen også en mere sofistikeret teknologiskalgoritmisk mekanisme, som sørger for, at Mae ikke bryder ud af dens positive cirkel af værdiskabelse. Maes vej ind i virksomheden indebærer nemlig en indrullering i virksomhedens bioproduktive arbejdsregulering: Den sørger for, at hendes krop og psyke fungerer, og hun dermed kan arbejde optimalt ved hjælp af en organisk "chip", som hun sluger, og som er koblet til et armbånd. Det går, at Cirklen kan overvåge hendes krops tilstande, mangler og behov, sygdomstegn, motion, diæt etc., alt sammen med det formål at forebygge og "give better care", så hun kan forblive den bedste version af sig selv (151-155) og altså vedblive med at producere værdi for Cirklen. Med andre ord ser vi igen den mere kyniske side af at løse "the scarcity gap" eller ideen om overflod og aldrig at mangle noget: mangel betyder en potentielt uproduktiv arbejder.

Dette anti-utopiske aspekt af den teknologiske indtrængning i og overvågning af kroppen finder sin mest interessante forestilling, der hvor teknologien bliver intimgjort som en måde at regulere Maes følelser og tilknytning. I nogle centrale passager får vi vist en særlig teknologisk mekanisme, som på kritiske tidspunkter sørger for, at Maes homologi med virksomheden, deres ideale synkroni, fastholdes, når hun, gennem teknologisk-algoritmisk mediering, hører sin egen stemme tale til sig. 
Dette kræver lige en baggrund. Som en del af at arbejde for Cirklen bliver Mae udvalgt til at være "one of the Circlers asked about her tastes, her preferences, her buying habits and plans, for use by the Circle's clients [...] You've been chosen because your opinions are crucial to us, and to our clients" (226-228). Retorikken blander igen en form for idealistisk humanisme, og det at være et vigtigt og værdifuldt individ, med den føromtalte, underliggende økonomiske realitet: "You're here because your opininons are valued. They're so valued that the world needs to know them [...] isn't that flattering?" (227). Cirklen søger at indfange hele Maes liv ved at få adgang til personlige informationer og forbrugsmæssige præferencer. Hun kan og bør svare på disse spørgsmål, som gives elektronisk via et headset, i løbet af hele det vågne liv. Mae bliver altså her synliggjort og samtidig reduceret til økonomisk subjekt på to måder, ved at hun, som nævnt, konstant arbejder for Cirklens indtjeningsstrøm gennem produktionen af økonomisk brugbar information for dens klienter, men også at hun som person bliver reduceret til og bestemt af disse præferencer.

Her opstår et muligt brud mellem Mae og Cirklen, da Mae føler et ubehag ved denne ide om, at menneskets liv og essens kan beskrives ud fra forbrugspræferencer, dvs. kun de aktiviteter, som har værdi i en kommerciel sammenhæng, hvor mennesket skaber indtjening for andre virksomheder. Som hun reflekterer: "Having a matrix of preferences presented as your essence, as the whole you? Maybe that was it [problemet, red.]. It was a kind of mirror, but it was incomplete, distorted" (125).

Men denne potentielle kritiske refleksion eller selvrefleksive "advarsel" bliver afmonteret gennem den føromtalte digitale stemme, som gør, at den konstante elektroniske strøm af spørgsmål om præferencer intimgøres med Mae selv, da hun nu hører sin egen stemme i sammenhæng med disse præference-spørgsmål. Hvis hun har for travlt med andre aktiviteter, eller hun bliver (kognitivt) uopmærksom - hvor uopmærksomhed er et indtjeningsbrud - så er stemmen det digitale signal, der skal minde hende om, at det er tid til at svare på spørgsmål. Hendes oplevelse af at høre sig selv er overvældende: "It was her voice, she knew, but then somehow it sounded less like her and more like some older, wiser version of herself [...] The voice seemed to lift Mae off her seat and spin her around. Every time she heard it, her heart picked up" (232-233). Cirklens indfangning eller teknologiske "capture" (230) af Maes stemme - noget ellers flygtigt og singulært - er en aktiv del af dens bioproduktive regulering af hendes liv. Denne mekanisme gør, at hendes arbejde med at levere information, hendes deling og synliggørelse af sine præferencer, dvs. selve det at blive et transparent og konstant økonomisk virksomt subjekt, kobles følelsesmæssigt til det ideale og bestræbelsen på at udfolde hendes fulde potentiale. Det økonomiske og det utopiske bliver "friktionsløst". Dette er tydeligt i en senere sekvens:

6 Her name, spoken by her voice, continued to hold its power over her. And she hadn't discovered why [...] It sounded this time, like a purer version of herself. [...] She wanted to hear it again, so she said nothing. "Mae." It was young woman's voice, a young woman's voice that sounded bright and fierce and capable of everything. "Mae." It was a better, more indomitable version of herself. "Mae." She felt stronger every time she heard it. (330-331) 
Vi er altså tilbage ved den homologi mellem Mae og Cirklen, som Cirklens akkumulationssystem er bygget op omkring: Det er på en indirekte måde mere Cirklen, der taler til hende end hende selv. Beskrivelsen er nærmest mystisk - ordets og stemmens magt - et algoritmisk genereret magisk ord, som giver Mae den følelse af renhed og idealitet, som korrelerer med følelsen af "the ideological purity of the Circle [...] [the] warming feeling of logic and order" (415). Vi er her tilbage ved artiklens indledning: Det er en følelse af at kunne klare alt, at være lige så ustoppelig som Cirklen og dens "irreversible bevægelse" selv. Det er følelsen af et renere og bedre selv, der er ved at skabe en renere verden, og dermed fjerner "the messiness of humanity" (491)" og det førnævnte "chaos of an orderless world" (370), som kendetegner fortiden og verdenen udenfor. Og man kan videre sige, at denne følelse af renhed, perfektion og idealitet knytter an til en form for "historisk teleologi" og fremtidssikkerhed: historien har en retning, et endemål, som er ved at blive skabt af hende og Cirklen, og fremtidens usikre åbenhed lukkes ned. Det er denne tryghed, som måske er det mest afgørende, for som Mae siger, efter med vilje at have hørt sin egen stemme tale til sig flere gange: "It felt like home" (377).

Cirklens kontrol med al informationsstrøm, dens monopolisering og kapitalisering af livet selv gennem indfangning og reducering af alle sine kognitive medarbejderes sociale aktiviteter til økonomiske aktiviteter, og subjektivitet til økonomisk subjektivitet, er produceret og reproduceret med eksemplet Mae gennem ideologiske (motivationelle) og teknologiske udbytningsmekanismer. Maes følelse af selv, værdier og ideale forestillinger sættes til at arbejde som parametre i virksomhedens indtjeningsstrøm. Den sørger for at regulere og manipulere det utopiske og skabende begær og holder hende rettet mod idealernes og det kognitives luftlag, der hvor man altid søger at blive "den bedste version af sig selv", så man ikke bliver konfronteret med den snavsede verden nedenunder eller udenfor. Den rå, økonomiske virkelighed forsvinder i lyset fra skærme, informationsdeling, interaktionen mellem "brain-power" og utopiske drømme om at ændre verden i Cirklens billede.

Men romanen er i sin kritiske anti-utopi, og skildring af en nær-fremtid-kapitalismes $\varnothing$ konomiske udbytning af hele menneskelivet, i sidste instans rettet mod et andet perspektiv, som vil blive de sidste konkluderende ord. Dette perspektiv vil dreje romanen over i en klassisk socialistisk forestillingsbane, som Cirklen i romanen hele tiden selv alluderer til, og hvis ideologiske arv den søger at appropriere i accentuering af "community", "participation", "sharing", men netop i den perverterede form af økonomisk værdiskabelse og profitmaksimering. Som det hedder et sted: "Infocommunism [...] paired with ruthless capitalistic ambition" (484). Givet det utopiske begær og eutopiens specifikke klasseperspektiv i romanen åbner den dog selv op for et modbillede eller en modforestilling, hvor virkeliggørelsen af en anden positiv utopi, dvs. en utopi for de mange og ikke for de få, må betyde reel økonomisk demokrati og medbestemmelse. Romanens anti-utopi åbner altså i sidste instans op for grundtrækkene af et andet utopisk begær, som peger mod en ophævelse af den økonomiske magt og det klasseforhold, som driver verden mod det specifikke utopiske mareridt. Med andre ord: utopien må være klasseløs. Dette er den moralske bedømmelse, som romanen åbner op for i sin helhed: Det er en utopisk horisont og realisering, der ligger uden for romanen, men som fremkommer gennem den specifikke anti-utopiske kritik. 


\section{Noter}

I Eutopia eller eutopien betyder den historisk-konkrete og virkeliggjorte utopi, dvs. et tidsligt og stedligt forankret idealfællesskab (Levitas 1990). Romanen skildrer det klassespecifikke utopiske begærs lokale og globale side: Mellem på den ene side, skildringen af det konkrete og lokalt virkeliggjorte campus-eutopi, og på den anden side, bestræbelsen på at udbrede og realisere denne eutopi på et globalt plan.

\section{Litteratur}

Baccolini, Raffaella and Tom Moylan (2003): "Introduction. Dystopia and Histories", i Raffaella Baccolini and Tom Moylan (red.): Dark Horizons - Science Fiction and Dystopian Imagination, New York/ London: Routledge, s. 1-12.

Berardi, Franco (2011): “What About the Dark Side of Multitude?", i Journal of Communication Inquiry 35(4), s. 310-312.

Berardi, Franco (2005): “what does cognitariat mean?", i Cultural Studies Review 11.2, s. 57-63.

Boutang, Yann Moulier (2008/2011): Cognitive Capitalism, Cambridge/Malden: Polity Press. Brand, Carina (2018): “'Feeding Like a Parasite': Extraction and Science Fiction in Capitalist Dystopia”, i William Davies (red.): Economic Science Fictions, Cambridge/London: Goldsmiths Press, s. 95-123.

Chang, Ha-Joon (2018): "Economics, Science Fiction, History and Comparative Studies", i William Davies (red.): Economic Science Fictions, Cambridge/London: Goldsmiths Press, s. 31-40 Davies, William (red.) (2018a): Economic Science Fictions, Cambridge/London: Goldsmiths Press. Davies, Williams (2018b): “Introduction to Economic Science Fictions", i William Davies (red.): Economic Science Fictions, Cambridge/London: Goldsmiths Press, s. 1-28.

Dyer-Witheford, Nick and Greig de Peuter (2009): Games of Empire, Minneapolis: University of Minnesota Press.

Dyer-Witheford, Nick (2015): Cyber-proletariat, London: Pluto Press.

Eggers, Dave (2013): The Circle, London: Penguin Books.

Fisher, Mark (2009): Capitalist Realism, Winchester/Washington: Zero Books.

Fisher, Mark (2018): "Foreword”, i William Davies (red.): Economic Science Fictions, Cambridge/ London: Goldsmiths Press, s. xi-xiv.

Fleming, Peter (2014): Resisting Work, Philadelphia: Temple University Press.

Galow, Timothy W. (2014): Understanding Dave Eggers, Columbia: University of South Carolina Press.

Gibson, William (2012): Distrust That Particular Flavor, London: Viking.

Horn, Laura (2018): "Future Incorporated?", i William Davies (red.): Economic Science Fictions, Cambridge/London: Goldsmiths Press, s. 41-58.

Jackson, Lily (2017): “The Circle is a warning”, i University Wire, Carlsbad: Auburn University, s. 1-4. Levitas, Ruth (1990): The Concept of Utopia, Hemel Hempstead: Philip Allan.

Levitas, Ruth and Lucy Sargisson (2003): "Utopia in Dark Times: Optimism/Pessimism and Utopia/ Dystopia”, i Raffaella Baccolini and Tom Moylan (red.): Dark Horizons - Science Fiction and Dystopian Imagination, New York/London: Routledge, s. 13-29.

Negri, Antonio and Carlo Vercellone (2018): “The Capital-Labour Relation in Cognitive Capitalism”, i Frederico Tomasello (red.): From the Factory to the Metropolis - Essays Volume 2, Cambridge/Medford: Polity Press, s. 102-112. 
O'Connell, Mark (2018): To Be a Machine, London: Granta.

Peters, Michael A. and Ergin Bulut (2010): “Introduction”, i Michael A Peters and Ergin Bulut (red.): Cognitive Capitalism, Education and Digital Labor, New York: Peter Lang, s. xxi-xl.

Suvin, Darko (2003): “Theses on Dystopia 2001”, i Raffaella Baccolini and Tom Moylan (red.): Dark Horizons - Science Fiction and Dystopian Imagination, New York/London: Routledge, s. 187-203.

Vercellone, Carlo (2009/2010): "The Crisis of the Law of Value and the Becoming-Rent of Profit", i Andrea Fumagalli and Sandro Mezzadra (red.): Crisis in the Global Economy, Los Angeles: Semiotext(e), s. 85-118.

Williams, Raymond (1956/2010): “Science Fiction”, i Andrew Milner (red.): Tenses of Imagination Raymond Williams on Science Fiction, Utopia and Dystopia, Bern: Peter Lang, s. 13-19.

Williams, Raymond (1961/2010): "The Future Story as Social Formula Novel”, i Andrew Milner (red.): Tenses of Imagination - Raymond Williams on Science Fiction, Utopia and Dystopia, Bern: Peter Lang, s. 44-50.

Williams, Raymond (1978/2010): “The Tenses of Imagination”, i Andrew Milner (red.): The Tenses of Imagination - Raymond Williams on Science Fiction, Utopia and Dystopia, Bern: Peter Lang, s. 115124. 